\title{
HUDÛD DAN HAM: ARTIKULASI PENGGOLONGAN HUDÛD ABDULLAHI AHMED AN-NA'IM
}

\author{
Dedy Sumardi \\ Fakultas Syariah IAIN Ar-Raniry \\ Jl. Ibn Sina Darussalam Banda Aceh, 23111 \\ e-mail: dedyfasyarar@yahoo.co.id
}

\begin{abstract}
Abstrak: $\underline{H} u d u ̂ d$ adalah ancaman hukuman yang ditegaskan al-Qur'an dan Sunnah berdasarkan teori hukuman yang menganut aspek reformasi. Penggolongan $\underline{h} u d u ̂ d$ ke dalam enam macam merupakan hasil ijtihad fukaha yang bersifat tekstual, dan nash sebagai sumber pengambilan $\underline{h} u d u ̂ d$ masih diperdebatkan. Sehingga muncul reaksi

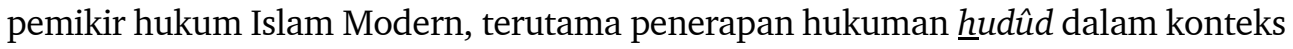
negara-bangsa berbenturan dengan prinsip penologis dan keuniversalan norma HAM. Tulisan ini mengkaji pemikiran an-Na'im dalam upaya menemukan kesesuaian antara syarî‘ $a h$ dan HAM. Hasil penelitian menunjukkan titik temunya adalah membatasi penerapan $\underline{h} u d u ̂ d$ ke dalam empat jenis, sesuai dengan prinsip ayat Makkiyah yang mengandung nilai mashlahah terealisir dalam teori naskh.
\end{abstract}

\begin{abstract}
Punishment and Human Rights: The Articulation of Abdullahi

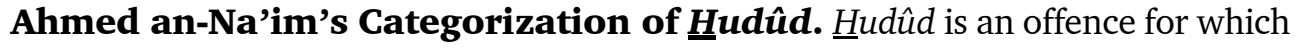
punishment prescribed by the Qur'an and Sunnah based on the theory of punishment constituting reformation aspect. The classification of $\underline{h} u d \hat{u} d$ into six categories is the product of literal legal deduction of Islamic jurisprudents, and that the legal argument for h $\underline{u}$ dûd is still debatable which lead to reactions of modern Islamic legal thinkers, especially on the application of hudûd in the context of those countries which are against penological principles and the universality of human right norms. This article studies the thoughts of an-Na'im in an attempt to seek confirmity between syarî‘ $a h$. This research reveals that the meeting point between the two would be the restriction of the application of $\underline{h} u d \hat{u} d$ into four types, in line with the prinples of Meccan verses bearing public interest values realized in the theory of abrogation.
\end{abstract}

Kata Kunci: $\underline{h} u d \hat{d} d, H A M$, mashlah̆ah

\section{Pendahuluan}

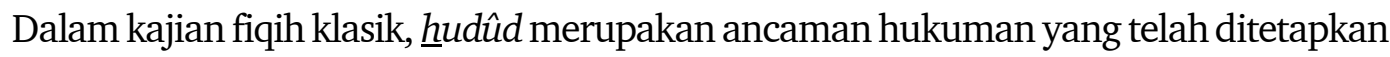
bagi pelaku kejahatan. Para pelaku kejahatan diancam dengan hukuman hadd, yaitu hukuman 
yang telah ditetapkan secara tegas dalam al-Qur'an dan Hadis sebagai hak Allah tanpa ada upaya pertimbangan bagi pihak korban untuk meringankan, mengurangi atau melebihkan jumlah hukuman yang telah ditetapkan, apalagi menggantikannya dengan hukuman lain. ${ }^{1}$ Dari segi kuantitas, para ahli hukum Islam membagi kejahatan yang tergolong ke

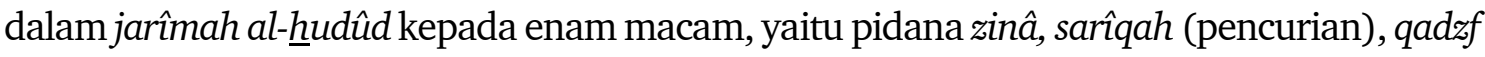
(tuduhan zina), syurb al-khamr (minuman khamar), hirîhbah (perampokan/pengacau keamanan), dan riddah (murtad). ${ }^{2}$

Keenam jenis kejahatan di atas adalah bentuk formulasi hukum yang dihasilkan dari ijtihad para ulama, yang kelihatan bersifat literalis dalam memahami aturan-aturan yang terdapat dalam nash. Baik al-Qur'an maupun Sunnah sendiri tidak membuat pembagian atas jenis-jenis $\underline{h} u d \hat{u} d$ ke dalam enam jenis. Jenis-jenis $\underline{h} u d \hat{d} d$ ini dibuat belakangan oleh para ulama untuk keperluan pemahaman dan penafsiran al-Qur'an sekaligus untuk pengembangan ilmu-ilmu yang berhubungan dengannya. Karena itu, di kalangan para ahli

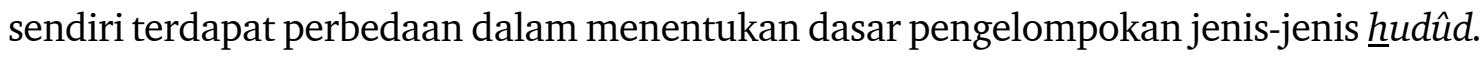

Pada tahap pelaksanannya, jenis-jenis h̆udûd sarat dengan berbagai sanggahan karena terdapatnya sebagian nash-nash yang dijadikan sumber pengambilan $\underline{h} u d \hat{u} d$ masih diperselisihkan di kalangan ulama. Dampak paling nyata dari sanggahan ini adalah ketika jenis-jenis h̆udûd ini dipantulkan kepada norma-norma hak asasi manusia (selanjutnya disebut HAM) melahirkan benturan dengan prinsip penologis ${ }^{3}$ dan keuniversalan norma HAM. ${ }^{4}$ Benturan tersebut dapat dicermati pada sifat dasar dan watak dari hukuman yang menurut prinsip penologis memberi kesan diskriminatif. Pandangan di atas muncul karena dominannya bentuk-bentuk hukuman fisik atau badan pada semua jenis hukuman $\underline{h} u d \hat{u} d$ yang disebutkan di dalam al-Qur'an dan Hadis, seperti hukum potong tangan untuk pidana pencurian, cambuk dan dilempari dengan batu (rajam) untuk pidana zina, disalib dan hukuman mati untuk pidana perampokan/ pengacau keamanan.

Tidak heran jika pada masa sekarang muncul upaya modifikasi hukum walaupun

${ }^{1}$ A. Djazuli, Fiqih Jinayah: Upaya Menanggulangi Kejahatan dalam Islam, Cet. 2 (Jakarta: RajaGrafindo Persada, 1997), h. 25.

${ }^{2}$ Muhammad 'Ata Alsid Sidahmad, Islamic Kriminal Law: The Hudud (First Published in Malaysia, 1995), h. 58-71; Wahbah al-Zuhaylî, Al-Fiqh al-Islâmî Wa Adillatuh, Cet. 4, Juz VII (Dimasyq: Dâr al-Fikr al-Mu'âshir, 2002), h. 5276.

${ }^{3}$ Dalam bahasa Indonesia istilah penologis diartikan dengan ilmu pidana, yaitu suatu cabang ilmu yang mengatur tentang kejahatan dan pelanggaran terhadap kepentingan umum dan perbuatan tersebut diancam dengan pidana yang merupakan suatu penderitaan. Sudarsono, Kamus Hukum, Cet. 2 (Jakarta: Rineka Cipta, 1999), h. 170.

${ }^{4}$ Hak asasi manusia adalah hak-hak yang melekat pada manusia karena martabatnya, dan bukan karena pemberian masyarakat atau negara. Dalam hak-hak itu terumus segi-segi kehidupan seseorang yang tidak boleh dilanggar karena ia seorang manusia. Oleh karena itu hak asasi manusia merupakan sarana perlindungan manusia terhadap kekuatan politik, sosial, ekonomis, kultural dan ideologis yang akan menindasnya apabila tidak dibendung. Franz Magnis Suseno, Kuasa dan Moral (Jakarta: Gramedia, 1986), h. 40. 
interpretasi yang dilakukan tetap terikat pada hasil ijtihad ulama terdahulu. Secara teoretis kajian terhadap paradigma dan teori $\underline{h} u d u ̂ d$ di atas bertolak dari pandangan dasar tentang kemanusiaan. Tujuan kajian ini sendiri adalah untuk melahirkan suatu konsep h̆ $u d u ̂ d$ yang dapat diterapkan di tengah masyarakat. Sedangkan secara praktis, perhatian utama penjatuhan

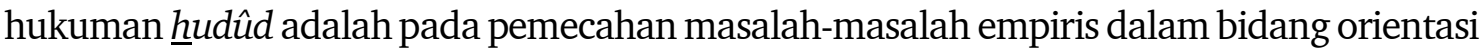
keadilan sosial, membebaskan manusia dan masyarakat dari ketidakadilan dan penindasan. Refleksi hukum h hudûd seperti ini kemudian diimplementasikan ke dalam masyarakat modern agar dapat memotivasi terjadinya keadilan.

Mencermati persoalan yang timbul di seputar reinterpretasi terhadap jenis-jenis hudûd dan problematika penerapannya, maka di antara tokoh yang menawarkan solusi bagi pemecahan persoalan di atas adalah Abdullahi Ahmed an-Na'im (selanjutnya disebut

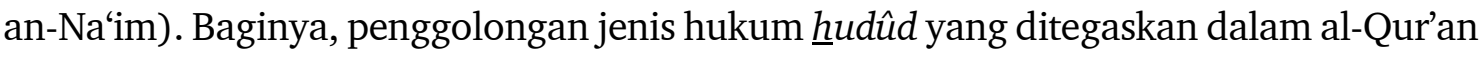
secara rinci adalah dibatasi pada empat jenis kejahatan, yaitu pencurian, perampokan, zinâ dan qadzf. ${ }^{5}$ Sedangkan pelanggaran terhadap minuman khamar dan riddah adalah jenis pelanggaran yang disepakati oleh para ahli hukum awal yang tidak mempunyai landasan

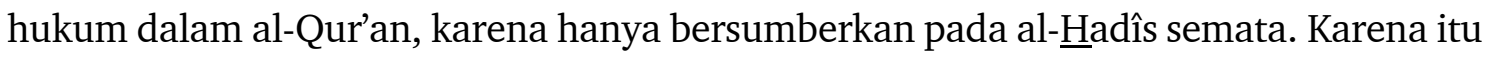
sangat memungkinkan bagi hakim untuk menetapkan hukuman terhadap dua jenis kejahatan (yang diistilahkan an-Na 'im dengan "pelanggaran") di atas menurut kebijaksanaannya sendiri ( $t a$ 'zîr), baik dalam bentuk menambah, mengurangi atau menghapuskan jumlah hukumannya. ${ }^{6}$

Seperti pidana riddah, menurut an-Na'im, penetapannya ke dalam jenis-jenis h $\underline{h}$ dûd dianggap melanggar hak asasi kebebasan beragama karena al-Qur'an tidak menetapkan hukuman apa pun bagi pelaku riddah. Penggolongan riddah sebagai hukuman hadd yang bisa dihukum mati hanya merujuk kepada Sunnah. ${ }^{7}$ Ia juga menyatakan bahwa al-Qur'an memiliki otoritas dalam menetapkan aturan hukum lebih tinggi. Di samping itu hadishadis yang menjelaskan pidana mati tersebut terkait dengan situasi tertentu, maksudnya hanya terbatas pada pelaku riddah yang memerangi Islam. ${ }^{8}$

Karena itu untuk menyingkirkan pelanggaran terhadap HAM, konsep hukum riddah dan semua konsekuensi perdata dan pidananya harus dihapuskan. Sedangkan otoritas sunnah yang menunjukkan kecenderungan pada konsekuensi pidana dan konsekuensi lainnya terhadap orang murtad dapat dijadikan sebagai suatu hukum peralihan. ${ }^{9}$

\footnotetext{
${ }^{5}$ Abdullahi Ahmed An-Na'im, Toward an Islamic Reformation: Civil Liberties, Human Right, and International Law (Syracuse University Press, 1996), h. 108.

${ }^{6}$ Ibid.

${ }^{7}$ M. A. Nasif, al-Tâj al-Jam‘i li al-Ushul, edisi IV (Kairo: Dâr Ihyâ’ al-Kutub al-Arabiyyah, t.t.), h. 18 .

${ }^{8}$ Kedudukan ini telah dijelaskan oleh Muhammad 'Abduh dan M. Rasyîd Ridâ dalam Tafsîr al-Manâr, Jilid V (Kairo: Dâr al-Kutub al-Aarabiyyah, t.t.), h. 327.

${ }^{9} \mathrm{An}-\mathrm{Na}$ 'im, Toward an Islamic, h. 109.
} 
Mengingat polemik yang muncul seputar persoalan $\underline{h} u d \hat{u} d$, agaknya gagasan yang dikemukakan oleh an-Na `im di atas perlu dikaji dan diuji kebenarannya. Temuannya agar dapat dijadikan sebagai tawaran alternatif bagi kebekuan penerapan hukum pidana Islam. Pemikiran ini menarik untuk diangkat karena di satu pihak an-Na 'im membagi hudûd ke dalam empat jenis, sedangkan fukaha ${ }^{10}$ umumnya membagi kepada enam jenis. Kajian ini sendiri dibatasi hanya pada pengelompokan yang ditawarkannya dalam kerangka konstitusional hukum pidana modern berpedoman pada sistem negara bangsa (nation state). Berdasarkan permasalahan yang telah diutarakan, terlihat bahwa masalah pokok yang menjadi objek tulisan ini adalah mengapa an-Na 'im berbeda dengan fukaha dalam

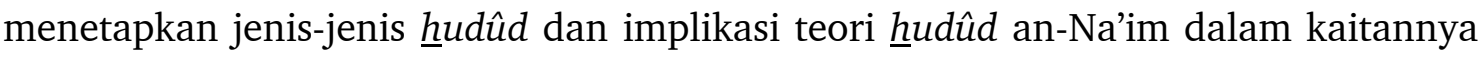
dengan norma-norma HAM.

Pembahasan tentang h hudûd dalam pandangan an-Na'im merupakan kajian yang amat dibutuhkan dalam konteks sekarang sehingga penilaian terhadap hukum Islam yang dianggap kejam dan melanggar HAM dapat dinetralisir. Di sisi lain menemukan dampak teori h̆ udûd an-Na imdalam kaitannya dengan penerapan hukum pidana Islam dengan konsep universal HAM. Dengan demikian, ini akan menambah kejelasan antara hukum "pidana syariah" dan hukum "pidana fiqh" di satu sisi serta "hukum pidana" yang ideal di sisi lain guna diterapkan dalam kehidupan masyarakat modern yang cenderung menjunjung tinggi nilai-nilai HAM.

\section{Hudûd: Problem Definisi}

Secara khusus an-Na'im dalam karyanya tidak membuat rumusan yang jelas mengenai definisi $\underline{h} u d u ̂ d$ yang sesungguhnya. Namun demikian bukan berarti an-Na'im tidak menyinggung sama sekali pandangannya mengenai definisi hudûd. Jika dicermati secara mendalam, ketika dia menguraikan pandangannya berkenaan dengan persoalan $\underline{h} u d \hat{u} d$ akan dapat diketahui bagaimana sesungguhnya konsep h hudûd yang ditawarkannya. Bagi an-Na 'im kendatipun konsep $\underline{h} u d u ̂ d$ berasal dari al-Qur'an, tetapi masih memunculkan problem definisi yang serius. ${ }^{11}$ Karenanya, tidak berarti dapat diterima begitu saja sebab memungkinkan untuk ditelaah dan dicermati secara mendalam. Terutama sebagaimana tercantum dalam surat al-Thalâq/65: 1 dan al-Nisâ'/2: 14.

Kata hudûd adalah bentuk jama' dari kata hadd, yang artinya batas (limit), batasan atau faktor yang membatasi. Dalam yurisprudensi Islam, istilah hadd digunakan untuk hukuman yang membatasi tindakan kejahatan, dan ia disebut $\underline{h} u d u \hat{d} .{ }^{12}$ Penggunaan

\footnotetext{
${ }^{10}$ Pengertian fukaha dalam tulisan ini mengacu kepada ulama mazhab sunni yang empat yaitu mazhab Hanafî, Mâlikî, Syâfiî̀ dan Hanbalî. Pemilihan keempat mazhab ini didasarkan atas kepopuleran dan banyaknya sumber rujukan yang ditulis oleh ulama masing-masing mazhab ataupun oleh tokoh-tokoh lain yang membahas pemikiran mereka.

${ }^{11} \mathrm{An}-\mathrm{Na}$ 'im, Toward an Islamic, h. 109 .

${ }^{12}$ Ibn Mandzûr, Lisân al- 'Arab, Juz III (Bairut: Dâr al-Fikr, 1999), h. 140.
} 
bentuk jama` (hudûd) mengindikasikan bahwa hadd (batas) yang ditentukan oleh Allah berjumlah banyak, dan manusia memiliki keleluasaan untuk memilih batasan tersebut sesuai dengan tuntutan situasi dan kondisi yang melingkupinya.

Dalam mengomentari surat al-Thalâq/65: 1 dan al-Nisâ'/65: 14 di atas, Muhammad Syahrûr memberikan analisis terutama pada ayat 14 surat al-Nisâ', kalimat ويتعد حسـدود mempunyai makna melanggar batas-batas (hukum)-Nya. Menurut Syahrûr, penggalan ayat ini menegaskan bahwa perbuatan maksiat (menolak untuk mengerjakan) dapat dilakukan terhadap Allah dan Rasul-Nya., tetapi pelanggaran batasan hukum hanya terjadi pada Tuhan saja, karena otoritas penentuan hukum syarî’ah yang terus berlaku selamalamanya hanya milik Allah saja. ${ }^{13}$

Dalam kajian fiqih al-jinâyah, para fukaha mengartikan hudûd sebagai 'uqûbah muqaddarah, yaitu ancaman hukuman yang kadar dan jenis hukuman telah ditetapkan dalam al-Qur'an, baik perbuatan maupun perkataan. ${ }^{14}$ Dalam penjabarannya, istilah 'uqûbah muqaddarah, kemudian menjadi istilah teknis ketika menjelaskan hukuman-hukuman yang berkaitan dengan pelanggaran jinâyah. Kewenangan dalam 'uqûbah muqaddarah

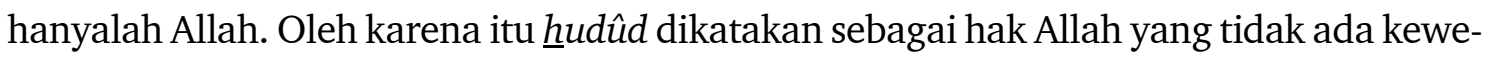
nangan bagi hakim mengurangi apalagi menambah jenis hukuman. Di samping itu, konsep h $\underline{u} u$ ûd yang dirumuskan oleh fukaha ini didasarkan pada penggunaan sunnah dan tradisi yang ada selalu dijadikan salah satu pertimbangan hukum tentang otentisitas dan penafsiran tradisi yang relevan. Kondisi ini sebagai justifikasi fukaha dalam merumuskan hudûd menjadi 'uqûbah muqaddarah.

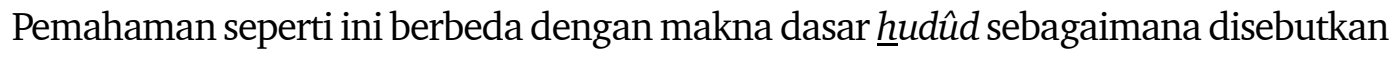
dalam al-Qur'an. Dasarnya term $\underline{h} u d u ̂ d ~ j a m a k ~ d a r i ~ h \underline{h}$ dd yang terdapat dalam kedua ayat di atas menengarai bahwa konsep $\underline{h} u d u ̂ d$ yang disebutkan dalam al-Qur'an berarti batasan hukum yang ditentukan Allah dan tidak boleh dilanggar. Menurut al-Na'îm, batasanbatasan hukum terhadap pelanggaran yang secara tegas disebutkan dalam al-Qur'an terbatas kepada empat jenis kejahatan, yaitu sarîqah, hirâbah, zinâ dan qadzf, karena hanya itulah pelanggaran-pelanggaran yang hukumannya disebut dalam nash al-Qur'an dengan jelas dan rinci. ${ }^{15}$ Argumen yang sama juga diungkapkan oleh Imâm al-Raghîb alIshfahânî mendefinisikan $\underline{h} u d u ̂ d$ menurut makna leksikal al-Qur'an sekaligus menegaskan keempat jenis kejahatan yang ditegaskan dalam al-Qur'an sebagaimana dipaparkan anNa'im. ${ }^{16}$

${ }^{13}$ Muhammad Syahrûr, al-Kitâb wa al-Qur'an: Qirâ 'ah Mu 'asharah (Kairo: Sinâ li al-Nasyr wa al-Ahallî, 1992), h. 452.

${ }^{14}$ 'Abd al-Qâdir 'Awdah, al-Tasyrî' al-Jinâ'îy al-Islâmî: Muqâranah bi al-Qânûn al-Wadh'îy, Jilid I (Bairût: Muassasah al-Risâlah, 1997), h. 207.

${ }^{15} \mathrm{An}-\mathrm{Na}$ 'im, Toward an Islamic, h. 108.

${ }^{16}$ Al-Raghîb al-Ashfahânî, Al-Mufradât fĩ Gharîb al-Qur'an (Bairût: Dâr al-Ma'rifah, 1986), h. 192-193. 
Sedangkan sunnah yang dijadikan fukaha dalam menetapkan jenis hukuman yang

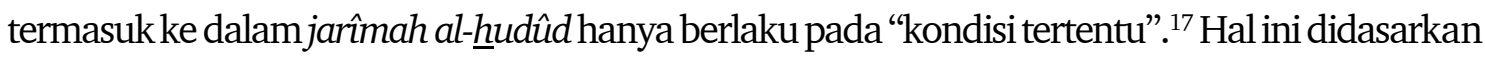
pada asas kepastian hukum secara tegas dalam jarîmah al-h̆udûd, mengharuskan "kondisi tertentu" direkomendasikan demi pertanggungjawaban pidana. Seperti terlihat pada jarîmah syurb al-khamr dan riddah, baik al-Qur'an maupun Sunnah tidak menyebutkan hukuman secara khusus. Ini terlihat dari perbedaan pendapat di kalangan para ulama terhadap banyaknya aspek pelanggaran yang memasukkan jumlah cambukan tertentu sebagai hukuman. Asumsi ini sebagai alasan an-Na `im menolak menggolongkan kedua jarîmah ini ke dalam $\underline{h} u d \hat{u} d .{ }^{18}$

Dari uraian di atas dapat dipahami bahwa hadûd yang dimaksudkan an-Na 'im adalah pelanggaran yang ditegaskan secara rinci dalam al-Qur'an saja. Sedangkan sunnah menjelaskan hukuman pelanggaran yang disebutkan dalam al-Qur'an berlaku pada situasi tertentu, misalnya penjelasan Sunnah mengenai pelanggaran syurb al-khamr dan riddah. Asumsi seperti ini didasarkan kepada "otoritas penentuan hukum syarî' ah" semata-mata adalah kewenangan Allah. Terkait dengan asumsi di atas, an-Na'im bukan tidak menerima keabsahan sunnah Nabi dalam jarîmah al-h̆udûd, ia mengakui sunnah juga memiliki fungsi dalam menjelaksan nash-nash al-Qur'an, tetapi khusus berlaku pada kasus-kasus tertentu yang relatif erat kaitannya dengan kondisi pada saat itu saja. Kajian terhadap kasus-kasus jinâyah yang mendapat legitimasi dari sunnah dalam pandangan an-Na'im perlu diberikan pemahaman yang utuh dengan mempertimbangkan aspek-aspek yang berhubungan dengan dinamika perkembangan masyarakat pada saat hukum itu diformulasikan menjadi hukum yang mengikat. Ketentuan hukum yang berasal dari Nabi SAW bersifat temporal (marhalî) sesuai dengan hikmah adanya Sunnah untuk ditaati di satu sisi, dan posisi Nabi sebagai teladan untuk berijtihad dalam lingkup batasan ketentuan Allah yang disesuaikan dengan kondisi objektif yang hidup dalam sejarah peradaban umat manusia.

\section{Kriteria $\underline{\text { Hudûd }}$}

An-Na'im membuat kriteria $\underline{h} u d \hat{u} d$ berbeda dengan kriteria yang ditetapkan oleh fukaha. Menurutnya, dalam jarîmah al-ȟhudûd terdapat hak yang harus dilindungi untuk kepentingan masyarakat. Ditinjau dari segi kepemilikan, hak dapat dibagi kepada hak Allah dan hak hamba.

\section{Haqq Allâh (Hak Allah)}

Menurut pandangan an-Na'im, yang dimaksud dengan hak Allah sama halnya seperti pemahaman ulama mengenai hak Allah yang terdapat dalam jarîmah al-ȟudûd.

${ }^{17} \mathrm{An}-\mathrm{Na}$ 'im, Toward an Islamic, h. 110.

${ }^{18}$ Ibid. h. 108. 
Hak ini merupakan salah satu hak yang harus dilaksanakan tanpa ada seorang pun yang dapat menggugurkannya, mengingat hak Allah disebut hak masyarakat. Dalam fiqh aljinâyat, yang menjadi hak Allah adalah hukuman yang ditetapkan berdasarkan kepentingan masyarakat atau disebut juga hak negara/hak umum. Hukuman yang menjadi hak Allah tidak dapat digugurkan oleh pihak yang dirugikan (keluarga korban), karena hukuman ini ditetapkan untuk ke-mashlahat-an masyarakat (berlaku umum), bukan ke-mashlahatan individu. Seperti hukuman bagi pencuri tidak gugur dengan pengampunan korban atau damai dengan pelaku pencuri setelah perkara itu sampai ke hakim. Begitu pula dalam kasus

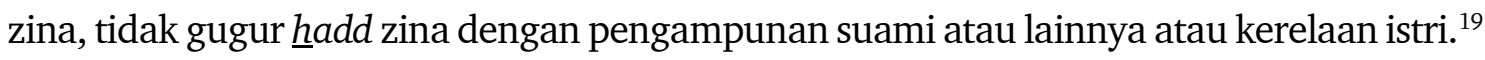

Hukuman yang dijatuhkan kepada pelaku pelanggaran terhadap hak Allah diterapkan hanya sekali saja terhadap dosa yang dilakukan berulang-ulang. Sekalipun berzina atau mencuri dilakukan berulang-ulang, tidak dihukum berkali-kali, karena tujuan dari hukuman adalah al-zajr (peringatan) dan al-rad ' (menakuti) dan dapat dicapai tujuannya dengan sekali hukuman. ${ }^{20}$ Kewenangan pelaksanaan hukuman ini adalah hakim, sebagai pelajaran (ta'dîb) bagi yang melanggarnya demi mencegah kekacauan dan sekaligus pemberi hukuman terhadap suatu kejahatan. ${ }^{21}$

\section{Haqq al-Âdami (Hak Hamba)}

Hak manusia yaitu hukuman yang menyangkut dengan kepentingan individu (berlaku khusus) dan dapat digugurkan oleh pihak yang dirugikan (keluarga korban) atau oleh pemerintah. ${ }^{22}$ Atas dasar ini, menurut Ibrahim Hosen, jarîmah al-qishâsh dan jarîmah al-

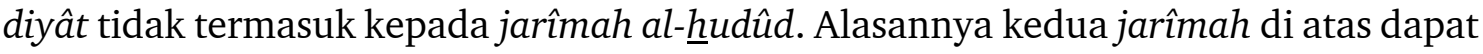
digugurkan oleh pihak yang dirugikan. ${ }^{23}$

Pada hakikatnya hak ini bertujuan untuk memelihara kemaslahatan setiap pribadi manusia. Hak ini ada yang bersifat umum dan ada yang bersifat khusus. Hak manusia yang bersifat umum seperti menjaga (menyediakan) sarana kesehatan, menjaga ketentraman, melenyapkan tindakan kekerasan (pidana), dan tindakan-tindakan lain yang dapat merusak tatanan masyarakat pada umumnya. Adapun hak yang bersifat khusus, seperti menjamin hak milik seseorang, hak istri mendapat nafkah dari suaminya, hak ibu memelihara anaknya dan hak bapak menjadi wali anak-anaknya, dan hak berusaha (berikhtiar) dan lain-lain yang bersifat untuk kepentingan pribadi (individu). Mengenai hak manusia ini seseorang

${ }^{19}$ Ibid.

${ }^{20}$ Syams al-Dîn al-Sarakhsî, Kitâb al-Mabsûth, Juz IX (Bairût: Dâr al-Ma'rifah, 1998), h. 185.

${ }^{21} \mathrm{Al}$-Zuhaylî, al-Fiqh al-Islâmî, Juz IV, h. 2845.

${ }^{22} \mathrm{~A}$ hmmad Fathi Bahnisi, Nazhariyyât fí al-Fiqh al-Jinâî al-Islâmî (Kairo: al-Syirkah al'Arabiyyah, 1963), h. 55.

${ }^{23}$ Ibrahim Hossen, "Jenis-jenis Hukuman dalam Hukum Pidana Islam: Reinterpretasi terhadap Pelaksanaan Aturan," dalam Jamal D. Rahman (ed.), Wacana Baru Fiqih Sosial: 70 Tahun K.H. Ali Yafie (Bandung: Mizan, 1997), h. 93. 
boleh menggugurkan haknya, memaafkannya dan mengubahnya, dan boleh pula mewariskannya kepada ahli waris. Di sini tampak adanya kebebasan berbuat dan bertindak atas dirinya sendiri. Termasuk pula hak asasi seperti hak hidup, merdeka, bertempat tinggal, mengeluarkan pendapat dan pikiran, terjaga kemuliaannya. ${ }^{24}$

Pada umumnya hak hamba tidak terdapat di dalam jarîmah al-ḩudûd, melainkan jarîmah al-qishâsh dan jarîmah al-ta'zîr. Khususnya pada jarîmah al-qadzf dicambuk 80 kali bagi orang yang menuduh (mahdzûf), terdapat dua hak yang harus dilindungi, yaitu hak Allah (menjaga kemuliaan manusia dan mencegah kerusakan di muka bumi) dan hak hamba (haqq al-mahdzûf) berupa penolakan kejahatan dituduh kepadanya untuk menjaga kemuliaan diri. Dari sinilah an-Na'im menilai bahwa dalam jarîmah al-hadûd terutama pada jarîmah al-qadzf hak hamba merupakan hak paling dominan daripada hak Allah. Dengan demikian hak hamba harus dilindungi karena ia termasuk ke dalam HAM.

\section{Implikasi Hudíd dalam Norma HAM}

Sejumlah teks syarî‘ah yang berbenturan dengan HAM merupakan teks yang menurut ulama selama ini termasuk kategori qath ‘î. Dalam tulisan ini dikemukakan beberapa contoh kasus yang diangkat an-Na'im berkaitan dengan pelanggaran konsep universal HAM PBB. Di antara contoh alternatif mengenai penerapan syarî‘ah Islam yang dianggap berbenturan dengan konsep HAM adalah yang terjadi di Sudan selama Presiden Numeiri menjabarkan program Islamisasi pada 1983-1985 dan hukuman $\underline{h}$ add yang dirancang oleh Hassan Turabi pada $1991 .{ }^{25}$ Aspek-aspek yang menjadi fokus dalam bahasan studi ini adalah kebebasan beragama dan hak-hak perempuan. Kesemuanya ini akan dipaparkan beriringan dengan pasal-pasal yang terdapat dalam Universal Declaration of Human Right.

\section{Hudûd dan Kebebasan Beragama}

Kesan yang sering dimunculkan ke permukaan ketika membahas persoalan kebebasan beragama adalah toleransi terhadap perbedaan agama dan menyerahkan kepada mereka yang akan memilih agama apa saja sesuai dengan kehendaknya tanpa memandang perbedaan jenis kelamin, warna kulit, suku dan ras. Para fukaha sepakat bahwa salah satu konsep tujuan dari maqâshid al-syarî‘ah sebagai benih lahirnya konsep HAM dalam Islam adalah kewajiban memelihara agama dari orang yang ingin menyelewengkannya, atau mempermainkannya, memaksa memeluknya atau berusaha mengeluarkannya (memurtadkannya). Hal ini diakui oleh fukaha dengan menetapkan adanya batasan (hukuman dan sanksi) murtad sebagai

\footnotetext{
${ }^{24} \mathrm{Al}$-Zuhaylî, al-Fiqh al-Islâmî, h. 2845.

${ }^{25}$ Mayer, Ambiguitas An-Na'im, h. 41-68.
} 
bagian dari syarîat tanpa mempertimbangkan apakah dalil-dalil yang dijadikan dasar tersebut telah sesuai dengan prinsip kebebasan beragama. ${ }^{26}$

Kesepakatan (ijmâ') ulama mengatakan bahwa orang murtad harus dibunuh bahkan dipaksa dengan segenap kekuatan untuk kembali kepada Islam, atau diberlakukan hukuman mati jika ia tetap menolak untuk kembali kepada Islam. Pertimbangan ulama adalah demi menjaga agama dari usaha-usaha pelecehan yang dianggap sebagai sumber pembentukan dan tegaknya kedaulatan umat Islam.

Bagi an-Na'im ketetapan hukum bunuh bagi orang murtad adalah salah satu bentuk pelanggaran terhadap norma-norma HAM pasal 18 dan 19 DUHAM yang menganut prinsip kebebasan dalam hal memilih keyakinan dan agamanya tanpa ada paksaan dan kebebasan mengemukakan pendapat. ${ }^{27}$

Contoh kasus yang dikedepankan an-Na'im adalah vonis hukuman mati yang diberikan kepada gurunya Mahmûd Muhammad Thâha dengan tuduhan murtad akibat ide-ide yang dilontarkannya. Kasus ini terjadi di saat pemerintahan Sudan dipegang oleh Presiden Ja` far Numeiri yang didampingi wakilnya Hasan al-Turâbî. Pengadilan Sudan yang ditangani oleh hakim al-Kabasyî mengeksekusi Thâha yang ketika itu berumur 79 tahun tanpa ada gugatan dari Wakil Presiden. ${ }^{28}$

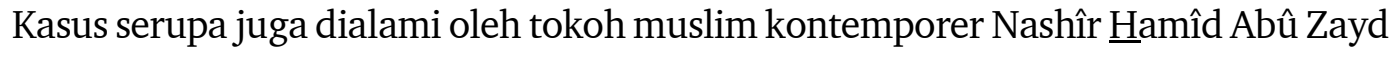
yang telah dituduh dan divonis murtad. Bahkan salah seorang menuntut untuk dilakukan perceraian dengan istrinya karena alasan murtad. Kasus yang menimpa Nashîr $\underline{\text { Hamîd }}$ Abû Zayd ini membuat ia hijrah ke Eropa bersama Mohammad Arkoun dan menjadi penasehat bidang penerbitan Ensiklopedi Barat berkaitan dengan al-Qur'an serta menerima tawaran dari Universitas Leiden Belanda. ${ }^{29}$

Dua contoh kasus murtad di atas menunjukkan bahwa pemaksaan dalam beragama sama halnya dengan sebuah penegasan bahwa dalam Islam terdapat pemberangusan terhadap kebebasan berakidah dan pemasungan terhadap HAM. Memperkuat argumentasinya, an-Na’im mengutip sejumlah ayat al-Qur'an yang tidak mendukung kebebasan beragama

${ }^{26}$ Q.S. al-Baqarah ayat 256.

${ }^{27}$ Pasal 18 DUHAM (Deklarasi Universal Hak Asasi Manusia) menyatakan setiap orang berhak untuk bebas berpikir, bertobat dan beragama; hak ini meliputi kebebasan berganti agama atau kepercayaan dan kebebasan untuk menyatakan agama atau kepercayaannya dalam bentuk beribadat dan menepatinya, baik sendiri maupun dilakukan bersama-sama dengan orang lain, baik sendiri maupun tersendiri. Serta Pasal 19 menyatakan setiap orang berhak untuk bebas berpendapat dan menyatakan pendapatnya. Baik itu meliputi kebebasan untuk memiliki pendapat-pendapat tanpa campur tangan pihak orang lain dan untuk mencari, menerima, dan menyampaikan informasi dan pendapat-pendapat dengan cara apa pun dan dengan tanpa memandang batas-batas.

${ }^{28}$ Taufik Adnan Amal dan Samsu Rizal Pangabean, Politik Syari'at Islam: Dari Indonesia Hingga Nigeria (Jakarta: Alvabet, 2004), h. 179.

${ }^{29}$ Thaha Jabir al-Ilwany, Tidak Ada Paksaan dalam Islam, terj. A. Fuad Mukhlis (Jakarta: Raja Grafindo Persada, 2005), h. 11. 
dan bertentangan dengan prinsip HAM adalah surat al-Taubah/9: 11-12, 29 dan 36. Dalam hal penyebaran Islam, ayat ini menawarkan tiga pilihan, yaitu: (1) Masuk Islam, (2) Keharusan membayar jizyah ${ }^{30}$ jikalau tidak mau masuk Islam, (3) Perang sebagai pilihan terakhir apabila kedua tawaran di atas tidak diindahkan. Aspek kedua dari ayat ini mengandung perlakuan diskriminasi bagi non-muslim dan ini tidak saja membatasi kebebasan beragama, tetapi membatasi kemerdekaaan dan persamaan hak sebagai warga negara yang dapat digolongkan pelanggaran prinsip HAM.

Adanya keharusan memilih salah satu dari tiga pilihan di atas, bagi an-Na'im ayat ini merupakan ayat yang tidak toleran terhadap kebebasan beragama. Padahal terdapat ayatayat lain yang bersifat toleran dalam beragama (al-Baqarah/2: 256). Ayat ini memberikan kebebasan kepada seseorang untuk menentukan pilihannya dalam memilih agama apa saja yang dia kehendaki, tanpa ada unsur paksaan dari siapa pun. Bagi al-Na'îm, sekalipun ayat ini turun pada masa Madinah awal, tetapi ia dapat saja dipandang sebagai ayat-ayat Makkiyah dengan kandungan isi ayat menekankan toleransi.

Pandangan serupa juga dilontarkan oleh M. Quraish Shihab. Ia mengatakan bahwa hukum bunuh bagi orang murtad sangat erat kaitannya dengan kondisi sosial setiap masyarakat. Dalam al-Qur'an tidak ditemukan indikasi keharusan menjatuhkan hukuman bunuh bagi orang murtad. Kalaupun ada hadis-hadis yang membicarakan tentang hukuman seperti itu, semata-mata hanyalah kebijaksanaan di dalam menata suatu masyarakat. ${ }^{31}$ Boleh jadi berlaku dalam masyarakat tertentu, tetapi tidak berlaku di dalam masyarakat yang lain. Sekalipun hukum bunuh berasal dari kebijakan Rasul, harus diperhatikan dalam konteks bagaimana kebijakan itu dianjurkan, apakah dalam konteks sebagai Rasul, sebagai pemberi fatwa, sebagai hakim yang menetapkan putusan atau sebagai pemimpin suatu masyarakat yang arah kebijaksanaannya akan terjadi perbedaan disebabkan perbedaan kondisi suatu masyarakat yang satu dengan masyarakat yang lain.

Pendapat di atas sejalan dengan apa yang dikatakan 'Âbid al-Jâbirî, di mana kondisi hukum bagi orang murtad dalam ajaran Islam tidaklah ditentukan oleh otoritas kebebasan, kebebasan beragama, melainkan ditentukan oleh otoritas apa yang sekarang disebut dengan pengkhianatan negara atau menyulut perang melawan masyarakat dan negara. ${ }^{32}$ Dalam kondisi seperti ini, bagi al-Jâbirî pembicaraan mengenai isu-isu tentang HAM dan kebebasan beragama lebih cenderung kepada kebebasan beragama secara individu dan tidak memasukkan kebebasan mengkhianati negara, masyarakat dan agama, kebebasan merampok dan merampas

${ }^{30}$ Abdullahi Ahmed An-Na'im, "Toward an Islamic Reformatioan: Islamic Law in History and Society Today," dalam Norani Othman (ed.), Shari'a Law and The Modern Nation-State: A Malaysian Symposium (Kuala Lumpur: Friedrich-Naumann-Stiftung, 1994), h.17.

${ }^{31}$ Muhammad Quraish Shihab, "Wawasan al-Qur'an Tentang Kebebasan Beragama," dalam Komaruddin Hidayat (ed.), Passing Over: Melintas Batas Agama (Jakarta: Gramedia Pustaka Utama, 1999), h. 190.

${ }^{32}$ Muhammad Abid al-Jabiri, Syura: Tradisi Partikularitas Universalitas, terj. Mujiburrahman (Yogyakarta: LKiS, 2003), h. 131. 
apa yang dimiliki orang lain. Hukum bunuh bagi orang murtad dalam pandangan ulama fiqih bukanlah semata-mata dikarenakan melanggar kebebasan beragama (pindah agama). Hukum bunuh tersebut ditujukan kepada orang murtad di samping pindah agama sekaligus melakukan pengkhianatan kepada agama dan negara serta membuat konspirasi dengan musuh.

\section{Hudûd dan Kesetaraan Jender}

Kasus hukum yang dikemukakan an-Na im dianggap diskriminatif dalam upaya penegakan HAM adalah kesaksian bagi wanita dalam masalah pidana zina (surat al-Nûr/ 24: 4). Di sini kesan diskriminasi didasarkan atas jenis kelamin, merupakan pelanggaran terhadap HAM yang tidak dapat dipertahankan lagi pada saat ini. ${ }^{33}$ Berkenaan dengan kesaksian, apakah wanita dapat dijadikan saksi hanya dalam bidang perdata saja atau lebih luas lagi. Para ulama baik di kalangan Syâfi'iyah, Hanafiyah, Mâlikiyah maupun Hanabilah berpendapat, sekalipun dalam redaksi berbeda, bahwa kesaksian wanita hanya terbatas pada masalah-masalah perdata, tidak dalam masalah-masalah pidana. ${ }^{34}$ Khusus ulama Syâfi'iyah sama sekali menolak kesaksian wanita dalam masalah pidana zina. ${ }^{35}$ Ini terlihat dari perkataan Syâfi'î yang kemudian diikuti oleh pengikutnya, bahwa tidak diterima kesaksian wanita dalam masalah $\underline{h} u d \hat{u} d$, perwalian, wasiat, serta tidak pula dalam bidang yang bukan bersifat harta benda. ${ }^{36}$

Penolakan ini tidak hanya ketika wanita memberi kesaksian tersebut tanpa lakilaki melainkan juga bersama laki-laki. Ketentuan ini juga berlaku pada pidana zina yang menjadi bagian pidana h̆udûd. ${ }^{37}$ Ulama Syâfi'iyah berpendapat bahwa saksi dalam kasus pidana zina haruslah mencapai empat orang laki-laki saja, sedangkan kasus pidana selain zina, mereka menetapkan jumlah saksi itu haruslah dua orang laki-laki. Dengan demikian terlihat bahwa ulama Syâfi'iyah telah mensyaratkan saksi dalam kasus pidana haruslah laki-laki. $^{38}$

Gambaran seperti di atas menunjukkan salah satu bentuk diskriminasi terhadap hak-hak perempuan dibandingkan dengan laki-laki. Kesaksian perempuan berbeda dengan laki-laki yaitu dua perempuan sama halnya dengan kesaksian seorang laki-laki. Pembedaan

${ }^{33} \mathrm{An}-\mathrm{Na}$ 'im, Toward an Islamic, h. 25-26.

${ }^{34}$ Ibn Ruysd, Bidâyah al-Mujtahid Wa Nihâyah al-Muqtashid, terj. Drs. Imam Ghazali Said Juz II (Semarang: Maktabah Usaha Keluarga, t.t.), h. 384.

35'Abd al-Qâdir 'Awdah, al-Tasyrî' al-Jinâ'îy al-Islâmî, Jilid II, h. 481.

36'Abd Allâh Muhammad ibn Idrîs al-Syâfiî̀, Al-Umm, Juz VII (Bairût: Dâr al-Fikr, t.t.), h. 50.

${ }^{37}$ Muhammad Atha al-Sayyid Sid Ahmad, al-Tasyri' al-Jina'iy al-Islami (Malaysia: Pustaka Negara Malaysia, 1995), h. 148.

${ }^{38}$ Al-Syairazî, Al-Muhadzdzab, Juz II (Mesir: Dâr Ihyâ' al-Kutub al-Ilmiyyah, t.t.), h. 333. 
berdasarkan jenis kelamin inilah yang dimaksudkan an-Na im dengan bias gender dan dianggap bertentangan dengan pasal 1 dan 2 Deklarasi HAM Universal. ${ }^{39}$

Bagi an-Na'im pasal ini problematis dan dilematis karena aturan syarî‘ah secara tegas membedakan perempuan dengan laki-laki dalam beberapa bidang kehidupan, termasuk dalam jarîmah al-h̆udûd. Ini berarti bahwa hak-hak perempuan lebih terbatas dibandingkan dengan laki-laki. Hak menjadi saksi hanya terbatas pada kasus perdata saja, yaitu dalam hal penetapan jumlah saksi (surat al-Baqarah/2: 282) satu berbanding dua, apabila dibandingkan dengan laki-laki (satu orang laki-laki berbanding dua orang perempuan). Ayat ini menunjukkan bahwa syarî‘ah menginginkan kesaksian dua orang perempuan sama halnya menempati kedudukan satu orang laki-laki dengan pertimbangan perempuan itu salah atau lupa. Inilah alasan yang diberikan al-Qur'an ketika jumlah saksi antara perempuan dan laki-laki dua banding satu. Hal senada diungkapkan oleh al-Sarakhsî, pada dasarnya perempuan tidak dapat diterima untuk memberikan kesaksian disebabkan oleh berbagai kekurangan yang mereka miliki, baik dari segi akalnya maupun agamanya. Mereka mudah sesat, pelupa, cepat terpedaya serta cenderung memperturutkan hawa nafsunya. Kendati demikian al-Sarakhsi mengakui bahwa keabsahan kesaksian wanita dalam hal-hal yang tidak diketahui oleh laki-laki adalah suatu pengecualian (istitsnâ), karena laki-laki tidak mengetahui hal tersebut, jadi tidak ada jalan lain kecuali menerima kesaksian wanita. ${ }^{40}$

Aturan syarî‘ah Islam yang bias gender ini umumnya didasarkan atas legitimasi alQur'an dan Sunnah, kelihatan cenderung menyudutkan kaum perempuan sebagaimana dipaparkan dalam ayat dan hadis di atas. ${ }^{41}$ Penilaian terhadap ayat tersebut mengisyaratkan kepada kekhawatiran seorang perempuan melakukan kesalahan atau lupa dalam memberikan kesaksian. Apalagi dalam masalah $\underline{h} u d u \hat{d}$ sangat diperlukan ketelitian dan kehati-hatian.

Walaupun penilaian di atas hanya sebatas kehati-hatian, dalam pandangan 'Âbid alJâbirî, sifat salah dan lupa bukanlah watak mendasar bagi perempuan, melainkan sematamata sangat terkait dengan kondisi sosial dan pendidikan yang ditempuhnya. ${ }^{42}$

${ }^{39}$ Pasal 1 Deklarasi HAM berkaitan dengan hak-hak perempuan adalah: "Semua orang dilahirkan merdeka dan sama dalam martabat dan hak-haknya. Mereka dikaruniai akal budi dan hati nurani, dan sebaiknya bertindak terhadap sesamanya dalam semangat persaudaraan." Sedangkan pasal 2: "Setiap orang mempunyai hak-hak dan kebebasan-kebebasan yang tercantum di dalam deklarasi ini tanpa perbedaan apapun, seperti perbedaan ras, warna kulit, jenis kelamin, bahasa, agama, tahanan politik atau paham yang lain, nasional atau asal usul sosial, hak milik, kelahiran ataupun status yang lain."

${ }^{40}$ Al-Sarakhsî, Al-Mabsûth, Juz XVI (Bairût: Dâr al-Maktab al-Ilmiyah, 1993), h. 142.

${ }^{41}$ Disinyalir bahwa al-Qur'an tidak terlepas dari bias gender mengingat ia turun di tengahtengah masyarakat Arab yang patriarkhi, masyarakat yang didominasi oleh kekuasaan laki-laki. Dalam budaya Arab, kedudukan perempuan sangat rendah, bahkan diangap suatu aib sehingga kehadiran perempuan dapat dijadikan alasan menguburnya hidup-hidup. Azyumardi Azra, "Ketentuan Fiqh tentang Gender," dalam Islam Substantif (Bandung: Mizan, 2000), h. 125-130.

${ }^{42}$ Al-Jabiri, Syura: Tradisi Partikularitas, h. 333. 
Hal yang perlu diperhatikan adalah bahwa penolakan ulama Syâfi'iyah terhadap kesaksian wanita dalam jarîmah al-h̆udûd adalah segi kejiwaan wanita. Selain itu, faktor waktu, tempat dan kultur di mana mereka memformulasikan fiqih itu sendiri sangat mempengaruhi pola ijtihad mereka. Pada zaman mereka wanita lebih banyak aktif dalam rumah tangga dan mendidik anak sehingga kemungkinan menyaksikan tindak pidana sangat sulit, apalagi masalah tindak pidana ini sangat berhubungan dengan kehormatan seseorang yang hampir dikatakan tidak ditemukan atau disaksikan, kalaupun ini terjadi orang lebih memilih diam atau tidak membawa kasus tersebut ke pengadilan karena hal ini merupakan masalah yang memalukan. Jika asumsi ini diterima, inilah sebagai suatu alasan mengapa para ulama sangat jarang membicarakan tentang masalah ini, tetapi tidak tertutup kemungkinan terjadi dalam suatu masyarakat pada waktu tertentu mengingat pola kehidupan modern yang telah memengaruhi kehidupan manusia.

Oleh karenanya apa yang diungkapkan al-Jâbirî ke-mashlahat-an dan kondisi sosial merupakan sesuatu yang berada di balik hukum atau ruh syarîah..$^{43}$ Ini dapat dirujuk pada kebijakan 'Umar ibn al-Khaththâb ketika ia tidak membagikan tanah pertanian Irak kepada para tentara, sebagaimana ditegaskan dalam al-Qur'an. Pertimbangan ke-mashlahatan yang dapat dipahami dari kasus ini adalah tidak membaginya kepada para tentara melainkan membiarkan tanah tersebut berada di tangan pemiliknya dan memungut pajak darinya. ${ }^{44}$ Pendapat senada juga diungkapkan oleh al-Syawkânî dengan mengutip pendapat

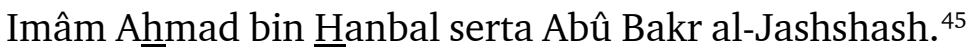

Untuk itu, an-Na'im menilai bahwa ke-mashlahat-an itu ada di setiap tradisi masyarakat. Kata al-Na 'îm, konsep mashlaḩah lebih potensial untuk direformasi. Dalam hal ini ia mengutip teori al-Ghazâlî (1058-1111 M) tentang maqâshid al-syar 'î sebagai pertimbangan bagi masalah kemanusiaan, meliputi pemeliharaan lima hal, yaitu: agama, jiwa, akal, keturunan dan harta. ${ }^{46}$ Dalam konteks ini an-Na'im juga setuju dengan teori yang menyatakan bahwa sejauh bukan menyangkut ibadah ritual, mashlaḩah dapat menentukan hukum bahkan melampaui nash al-Qur'an dan Sunnah, juga ijmâ' ketika diketahui ada ke-mashlahatan umum. ${ }^{47}$ Menurut teori ini mashlah̆h lebih penting dan bila perlu dapat mengabaikan

${ }^{43}$ Ibid. h. 135.

${ }^{44}$ Muhammad Baltâjî, Manh hâj 'Umar bin al-Khaththâb fí Tasyrî' (Kairo: Maktabah al-Syabâb, 1998), h. 140.

${ }^{45}$ Muhammad ibn 'Alî al-Syawkînî, Nayl al-Awthâr, Jilid VII (Bairût: Dâr al-Jayl, t.t.), h. 268.

${ }^{46} \mathrm{An}-\mathrm{Na}$ 'im, Toward an Islamic, h. 25-26.

${ }^{47}$ Ibrahim Hosen "Beberapa Catatan Tentang Reaktualisasi Hukum Islam" dalam Kontekstualisasi Ajaran Islam (Jakarta: IPHI/Paramadina, 1995), h. 254-262. 
teks. ${ }^{48}$ Dengan kata lain, sesuatu yang manshûsh belum tentu bernilai qath $\hat{\imath}$, sebagaimana dikatakan Masdar F. Mas'udi, yang qath î adalah mashlahahah itu sendiri. ${ }^{49}$

Mencermati dan menelaah uraian di atas, berdasarkan data-data yang diperoleh dapat dikatakan bahwa pendapat an-Na'im yang keberatan menerima kesaksian wanita di bidang perdata saja, dan bukan di bidang pidana bukanlah sesuatu hal yang baru dan asing dalam khazanah pemikiran Islam, melainkan telah dibicarakan oleh para ulama terdahulu. Perlu ditegaskan bahwa yang dikatakan baru dalam pemikiran an-Na 'im adalah ketika dia mengaitkan kasus di atas dengan menyebutnya sebagai bagian dari bentuk pelanggaran HAM. Jika diteliti lebih lanjut pendapat ulama terdahulu ditemukan bahwa

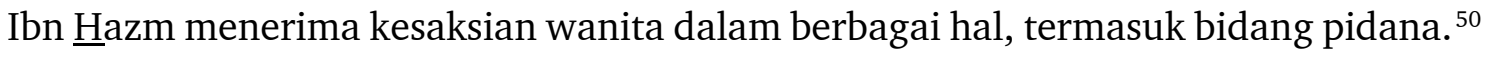

Sejalan dengan pendapat di atas, Muhammad al-Ghazâlî memberi komentar terhadap pendapat yang menolak kesaksian wanita bahwa timbul penyimpangan dalam pemikiran muslim yang sama sekali menjauhkan kaum wanita dari kesempatan memberikan kesaksiannya dalam berbagai bidang peradilan menyangkut masalah qishâsh dan tindak pidana yang bersangkutan dengan nyawa dan kehormatan manusia. ${ }^{51}$

Uraian di atas menunjukkan beberapa contah kasus di mana mayoritas ulama menggolongkannya ke dalam jarîma h al-ȟudûd yang oleh an-Na im dianggap diskriminatif sekaligus bertentangan dengan HAM. Dari uraian di atas persoalan yang menjadi perhatian utama gagasan al-Na 'îm, adalah: Pertama, keinginannya mengurangi jumlah kasus yang termasuk $\underline{h} u d u ̂ d$, yaitu dari enam menjadi empat seperti sirqah, zinâ, hirâbah, qadzf. Sedangkan yang lainnya dikarenakan ketidaktegasan dalil Sunnah yang menunjukkan hukuman bagi pelaku kejahatan tersebut maka an-Na 'im memasukkannya ke dalam jarîmah al-ta'zîr. Kedua, keinginan untuk meminimalkan sanksi hukumnya. Sanksi h̆udûd yang disebutkan dalam al-Qur'an dipahami sebagai sanksi maksimal yang kejam dan mengurangi kehormatan atas martabat kemanusiaan, maka dalam praktiknya perlu diringankan (diminimalkan). Karena ayat-ayat yang mengaturnya cukup tegas, dan tidak ada cara yang sah untuk meniadakan hukum tersebut dan paling mungkin adalah membatasi pemberlakuannya.

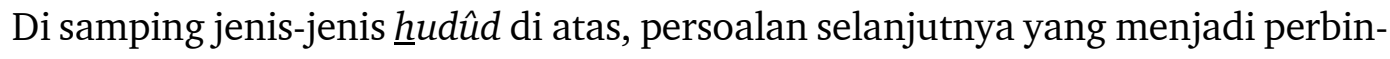
cangan an-Na'im adalah berkenaan dengan sanksi hukum hudûd yang tercantum dalam al-Qur'an dan hadis adalah hukuman maksimal yang kejam dan mengurangi kehormatan atas martabat kemanusiaan. Oleh karena itu batas maksimal hukuman ini sudah seharusmya

${ }^{48}$ Dalam sebuah kaidah fiqh ditegaskan: "Jika kemaslahatan bertentangan dengan teks maka yang diambil adalah kemaslahatan karena ia merupakan dasar lahirnya teks itu. Masdar F. Mas'udi "Meletakkan Kembali Mashlahat Sebagai Acuan Syarî‘ah," dalam Ulumul Qur'an, Vol. VI, No. 3, 1995, h. 94-99.

${ }^{49}$ Masdar F. Mas'udi, Agama Keadilan (Jakarta: Pustaka Firdaus, 1993), h. 20-21.

${ }^{50} I b n u$ Hazm, Al-Muhallâ, Juz IX (Mesir: Idârât al-Thaba'ah al-Munîriyyah, 1351), h. 195-196.

${ }^{51}$ Muhammad al-Ghazali, Studi Kritis atas Hadis Nabi, terj. Muhammad al-Baqir (Bandung: Mizan, 1998), h. 76. 
dilakukan upaya pembatasan penerapan hukuman maksimal menjadi hukuman minimal. Hukuman maksimal yang dimaksudkan oleh an-Na'im adalah seperti hukuman potong tangan bagi pelaku pencurian, hukuman rajam bagi pezina muhshan dan cambuk bagi pezina ghayr muhshan.

Pandangan an-Na'im di atas sejalan dengan teori limit/batas (nazhariyyât al-ȟhudûd) Muhammad Syahrûr yang memiliki batas atas (al-hadd al-a'lâ) dan batas bawah (alhadd al-adna.${ }^{52}$ Dalam kasus pencurian yang menjadi batas atas adalah hukuman potong tangan sehingga tidak boleh memberikan hukuman yang melebihi dari itu. Sedangkan batas bawah adalah hukuman lebih rendah selain potong tangan sesuai dengan kadar barang yang dicuri. ${ }^{53}$ Baik an-Na'im maupun Syahrûr sama-sama menginginkan diterapkannya hukuman minimal, bukan hukuman maksimal. Jika hukuman minimal diterapakan seperti kasus di atas, menurut 'Abd al-Qâdir 'Awdah tidak dinamakan jarîmah al-h̆udûd, melainkan perbuatan ta'zîr yang seharusnya dikenakan hukuman hadd. Akan tetapi karena perbuatan itu tidak memenuhi persyaratan untuk dihukum $\underline{h} a d d$, maka yang demikian itu digolongkan sebagai perbuatan ta'zîr yang berkaiatan dengan $\underline{h} u d \hat{d} d . .^{54}$

Lebih lanjut an-Na'im mengatakan hukuman yang terkandung di dalam jarîmah al-h̆udûd secara manusiawi hukuman-hukuman yang bersifat fisik seperti potong tangan bagi pencuri dan lemparan batu hingga mati bagi pelaku zina adalah hukuman terlalu

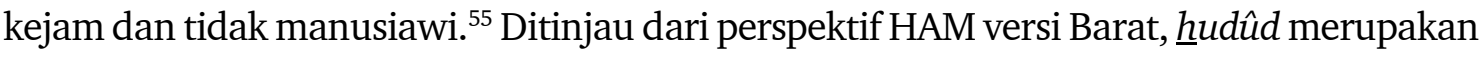
contoh hukuman yang menyalahi aturan, larangan atas perlakuan atau hukuman yang merendahkan martabat manusia. ${ }^{56}$ Kesan mengerikan dari potong tangan dan kaki, penyaliban, hukuman mati dan dera adalah ciri khas hukuman syarî́ah yang harus diterapkan ketika terjadi pelanggaran $\underline{h} u d u ̂ d$.

Bahkan Fazlur Rahman memberi komentar bahwa hukuman potong tangan itu sangat mengerikan dan sadis. Padahal hukuman potong tangan ini bukan berasal dari ajaran Islam melainkan lahir dalam tradisi masyarakat Arab sebelum Islam. ${ }^{57}$ Bagi Rahman

${ }^{52}$ Syahrûr, al-Kitâb wa al-Qur'an, h. 453-454.

${ }^{53} \mathrm{M}$. Amin Abdullahi, "Paradigma Alternatif Pengembangan Ushul Fiqh dan Dampaknya pada Fiqh Kontemporer," dalam M. Amin Abdullahi et al., Mazhab Jogja (Jogjakarta: Ar-Ruzz Press, 2002), h. 136.

${ }^{54}$ Abd al-Qâdir 'Awdah, al-Tasyrî' al-Jinâ'îy al-Islâmî, Juz I, h.133.

${ }^{55}$ Lampiran Pasal 5 Deklarasi Universal dan Pasal 7 Perikatan Hak-Hak Politik dan Sipil; An-Na'im, Toward an Islamic, h. 113.

${ }^{56}$ Mayer, Ambiguitas An-Na'im., h. 53.

${ }^{57} \mathrm{Hukuman}$ potong tangan merupakan pilihan yang paling rasional disaat itu yang berdampak pada melindungi eksistensi masyarakat karena tidak ada lagi batas-batas, pagar dan harta simpanan, dengan pertimbangan; Pertama untuk menghentikan sama sekali kemungkinan mengulangi pencurian. Kedua, untuk memberikan tanda pada seorang yang pernah mencuri agar ia dikenal dan orang berhatihati padanya. Al-Jabiri, Agama, Negara dan Penerapan, h. 167. 
ayat فـــــ (faqtha 'û aydiyahumâ) ditafsirkannya sebagai perintah menghalangi tangan-tangan pencuri untuk mencuri, yaitu dengan cara perbaikan ekonomi. ${ }^{58}$

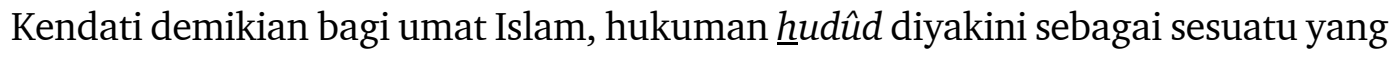
patut dan akan mencapai ke-mashlahat-an individual dan sosial yang muncul dari aspek retribusi dan deterrence, karena ketentuan hukuman tersebut adalah ketetapan Tuhan. Ditinjau dari segi sistem, hukum pidana Islam lebih kuat mengadopsi aspek balasan/ganti rugi (retribusi) dan penjeraan (deterrence) jika di bandingkan dengan sistem pidana lain. ${ }^{59}$

Islam memandang sifat penjeraan merupakan hal yang paling utama dalam pemberian hukuman. Pandangan seperti ini dapat ditelusuri pendapat ulama berkaitan dengan tujuan dijatuhkannya hukuman. Karena pandangan seperti inilah al-Mâwardî mendefinisikan hudûd sebagai "hukuman pencegahan" yang diciptakan oleh Tuhan untuk mencegah manusia melakukan pelanggaran terhadap apa yang dilarang-Nya dengan mengesampingkan apa yang diperintahkan-Nya. ${ }^{60}$ Sifat penjeraan dalam teori hukuman dalam Islam, baik penjeraan terhadap pelaku kejahatan maupun masyarakat. Aspek inilah yang menjadi argumen mayoritas para ulama mendukung pandangan teori penjeraan sebagai motivasi di balik ketetapan Tuhan tentang hukuman hadd.

Mencermati argumen di atas, an-Na'im menilai pentingnya sifat rasional dalam pemberian hukuman yang lain selain dua aspek retribusi dan deterrence sebagaimana disebutkan pada penjelasan sebelumnya. Perhatian an-Na'im mengarah kepada sifat reformasi (reformation) dari suatu hukuman pidana. ${ }^{61}$ Bagi para kriminolog reformasi itu sendiri lebih sinonim dengan arti "pengobatan" (cure). Kecenderungan ini lebih didasarkan pada suatu pemikiran bahwa orang yang melakukan tindak kriminal tidak lagi tepat dipandang sebagai "orang yang jelek" akan tetapi "orang yang sakit". Penekanan pada aspek reformasi ini mewarnai sistem hukum pidana yang berlaku di hampir semua negara Barat.

Dri kenyataan di atas tidaklah berlebihan jika dikatakan bahwa pemikiran an-Na 'im lebih banyak dipengaruhi oleh teori hukuman yang berlaku di dunia Barat. Ia mengadopsi metode kerangka keilmuan Barat. Dengan cara pandang seperti ini, an-Na 'im memandang Islam sebagai konsep legal, sehingga apa yang tertuang secara tegas dan eksplisit di dalam nash (manshush) dinilai prinsip dan bernilai qath $\hat{\imath}$. Di sini an-Na'im terlalu simplistis dalam memandang syarî‘ah seakan identik dengan 'uqûbah, dan 'uqûbah identik dengan syarî‘ $a h$ sehingga dengan mereformasi masalah 'uqûbah sama halnya seperti mereformasi syarî‘ $a h$.

Untuk menepis kegelisahan an-Na'im di atas, dalam sistem syarî‘ah ada hierarki pada tingkat tertinggi yaitu mashlaḩah, kemudian 'adâlah (keadilan), kulliyah al-khamsah,

${ }^{58}$ Fazlur Rahman, Islam (Bandung: Pustaka Salman, 1984), h. 330.

${ }^{59}$ Mohammad S. El-Awa, Punishment in Islamic Law (Budianapoliss: American Trust Publiations, 1982), h. 30.

60'Alî bin Muhammad bin Habîb al-Mâwardî, al-A $\underline{h} k a ̂ m$ al-Shulthâniyyah, Cet. 2 (Mesir: Mushthafâ al-Bâbî al-ㅂalabî, 1996), h. 221.

${ }^{61} \mathrm{An}-\mathrm{Na}$ 'im, Toward an Islamic, h. 112. 
maqâshid al-syarî́ah dan baru uqubbah. Jika argumen ini diterima, hemat penulis Islam itu harus dipandang sebagai ajaran ethic, yaitu sebagai suatu sistem etika kehidupan dalam segala bidang yang bernilai mashlahah. Dalam konteks ini pada dasarnya yang dikembangkan dalam sistem syarî́ah bukanlah aspek tanzîr, yaitu hal-hal yang menakut-nakuti melainkan aspek tabsyîr, ajaran yang membahagiakan dan mensejahterakan.

\section{Penutup}

Berdasarkan pandangan al-Na'îm, hadûd adalah hukuman yang secara tegas terdapat dalam al-Qur'an dan hadis yang didasarkan pada teori hukuman yang menganut aspek reformasi. Karena itu, jenis-jenis h $\underline{h}$ dûd yang diakui keabsahannya secara tegas disebutkan dalam al-Qur'an dan hadis adalah empat jenis kejahatan yaitu qadzf, zinâ, sariqah, dan hirâbah. Sedangkan jarîmah al-khamr dan riddah -yang menurut fukaha termasuk dalam kategori h̆ hudûd- digolongkan ke dalam jarîmah al-ta'sîr atau apa yang disebutnya sebagai hukum peralihan.

Penolakan an-Na'im terhadap kedua jarîmah yang disebutkan terakhir mengingat nash-nash yang menjelaskan hukumannya tidak disebutkan secara tegas dalam al-Qur'an, melainkan hanya sebatas hukuman moral saja. Penjatuhan hukuman tersebut merupakan kebijakan penguasa yang disebut dengan siyâsah syariyyah. Akan tetapi ketegasan hukumannya diperoleh dalam hadis Nabi yang statusnya masih diperselisihkan oleh para ulama dari segi keotentikannya. Di samping itu juga rasionalisasi teori hukuman dalam jarimah $\underline{h} u d u ̂ d$ di kalangan fukaha hanya berdasarkan aspek retribusi (balasan) dan deterrence (penjeraan). Sedangkan an-Na ' im cenderung melihat aspek reformasi yang umumnya digunakan dalam sistem hukum pidana yang berlaku di negara-negara Barat.

Untuk menjembatani ketimpangan di atas maka an-Na'im mengkombinasikan hukum pidana Islam sekaligus memberi penghormatan kepada standar HAM internasional dengan

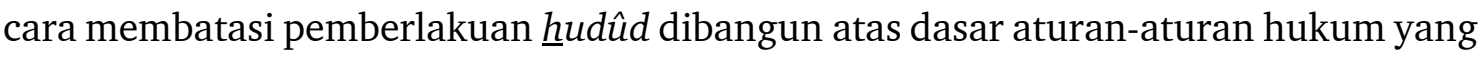
termuat dalam ayat-ayat periode Makkah yang menghargai persamaan dan perbedaan sasarannya (khitabnya). Di sini an-Na'im menjadikan konsep mashlahah sebagai landasan dalam mencari titik temu antara syarî́ah dan HAM. Bentuk mashlaḩah diperolehnya dalam teori nasakh terbalik yang dielaborasi dari gurunya Mahmûd Thâha. Melalui teori nasakh ini seluruh ayat Madaniyah dan norma hukum yang diatur dalam syarîah berlawanan bagi penegakan HAM, dinyatakan tidak berlaku (mansûkh). Sebagai penggantinya adalah dengan cara mengaktualisasikan ayat-ayat Makkiyah yang bersifat universal dan toleran sesuai dengan prinsip HAM.

Apa yang diinginkan an-Na'im adalah upaya memikir ulang (rethinking) bangunan hukum pidana Islam disesuaikan dengan norma-norma HAM dan lingkungan masyarakat modern yang plural dan terdiri dari berbagai nilai kultural yang dianut. Solusi yang ditawarkannya senantiasa umat Islam siap untuk mendesakralisasikan hukum Islam dan membawanya sesuai dengan alur sejarah peradaban umat manusia. 


\section{Pustaka Acuan}

'Abduh, Muhammad dan M. Rasyîd Ridhâ. Tafsîr al-Manâr, Jilid V. Kairo: Dâr al-Kutub alArabiyyah, t.t.

Abdullah, M. Amin. "Paradigma Alternatif Pengembangan Ushul Fiqih, dan Dampaknya pada Fiqih Kontemporer, dalam M. Amin Abdullah (et al.) Mazhab Jogja. Jogjakarta: Ar-Ruzz Press, 2002.

Ahmad, Muhammad Atha al-Sayyid Sid. al-Tasyrî́ al-Jinâ‘iy al-Islâmi. Malaysia: Pustaka Negara Malaysia, 1995.

Amal, Taufik Adnan dan Samsu Rizal Pangabean. Politik Syari'at Islam: Dari Indonesia Hingga Nigeria. Jakarta: Alvabet, 2004.

Al-Ashfahânî, Al-Raghîb. Al-Mufradât fí Gharîb al-Qur'ân. Bairût: Dâr al-Ma rifah, 1986.

'Awdah, 'Abd al-Qâdir. al-Tasyrî' al-Jinâ'îy al-Islâmî: Muqâranah bi al-Qânûn al-Wadh 'îy, Jilid I. Bairût: Muassasah al-Risâlah, 1997.

Azra, Azyumardi. "Ketentuan Fiqih tentang Gender," dalam Islam Substantif. Bandung: Mizan, 2000.

Bahnisî, Ahmad Fathi. Nazhariyyât fĩ al-Fiqih al-Jinâî́ al-Islâmî. Kairo: al-Syirkah al-Arabiyyah, 1963.

Baltâjî, Muhammad. Manhâjj 'Umar bin al-Khaththâb fì Tasyrî'. Kairo: Maktabah al-Syabâb, 1998.

Djazuli, A. Fiqih Jinayah: Upaya Menanggulangi Kejahatan dalam Islam, Cet. 2. Jakarta: RajaGrafindo Persada, 1997.

El-Awa, Mohammad S. Punishment in Islamic Law. Budianapoliss: American Trust Publication, 1982.

Al-Ghazâlî, Muhammad. Studi Kritis atas Hadis Nabi, terj. Muhammad al-Baqir. Bandung: Mizan, 1998.

Hazm, Ibn. Al-Muhallâ, Juz IX. Mesir: Idârât al-Thaba'ah al-Munîriyyah, 1351.

Hosen, Ibrahim. "Beberapa Catatan Tentang Reaktualisasi Hukum Islam," dalam Kontekstualisasi Ajaran Islam. Jakarta: IPHI/Paramadina, 1995.

Hosen, Ibrahim. "Jenis-jenis Hukuman dalam Hukum Pidana Islam: Reinterpretasi terhadap Pelaksanaan Aturan," dalam Jamal D. Rahman (ed.). Wacana Baru Fiqih Sosial: 70 Tahun K.H. Ali Yafie. Bandung: Mizan, 1997.

Al-Ilwany, Thaha Jabir. Tidak Ada Paksaan dalam Islam, terj. A. Fuad Mukhlis. Jakarta: RajaGrafindo Persada, 2005.

Al-Jabiri, Muhammad Abid. Syura: Tradisi Partikularitas Universalitas, terj. Mujiburrahman. Yogyakarta: LkiS, 2003.

Al-Mâwardî, 'Alî bin Muhammad bin Habîb. al-Ahkâm al-Shulthâniyyah, Cet. 2. Mesir: Mushthafâ al-Bâbî al-Halabî, 1996.

Mandzûr, Ibn. Lisân al-`Arab, Juz III. Bairut: Dâr al-Fikr, 1999. 
Mas'udi, Masdar F. Agama Keadilan. Jakarta: Pustaka Firdaus, 1993.

Mas'udi, Masdar F. "Meletakkan Kembali Mashlahat Sebagai Acuan Syarî‘ah,” dalam Ulumul Qur'an, Vol. VI No. 3, t.t.

An-Na'im, Abdullahi Ahmed. Toward an Islamic Reformation: Civil Liberties, Human Right, and International Law. Syracuse: University Press, 1996.

An-Na'im, Abdullahi Ahmed. "Toward an Islamic Reformatioan: Islamic Law in History and Society Today," dalam Norani Othman (ed.). Shari'a Law and The Modern NationState: A Malaysian Symposium. Kuala Lumpur: Friedrich-Naumann-Stiftung, 1994.

Nasif, M. A.. al-Tâj al-Jâm ‘i li al-Ushûl, ed. IV. Kairo: Dâr Ihyâ’ al-Kutub al-'Arabiyyah, t.t.

Rahman, Fazlur. Islam. Bandung: Pustaka Salman, 1984

Ibn Rusyd. Bidâyah al-Mujtahid Wa Nihâyah al-Muqtashid, Juz II, terj. Drs. Imam Ghazali Said. Semarang: Maktabah Usaha Keluarga, t.t.

Al-Sarakhsî, Syams al-Dîn. Kitâb al-Mabsûth, Juz IX. Bairût: Dâr al-Ma'rifah, 1998.

Al-Sarakhsî. Al-Mabsûth, Juz XVI. Bairût: Dâr al-Maktab al-Ilmiyah, 1993.

Al-Syâfi'î, 'Abd Allâh Muhamammad ibn Idrîs. Al-Umm, Juz VII. Bairût: Dâr al-Fikr, t.t.

Al-Syairazî. Al-Muhadzdzab, Juz II. Mesir: Dâr Ihyâ' al-Kutub al-Ilmiyyah, t.t.

Al-Syawkânî, Muhammad ibn 'Alî. Nayl al-Awthîr, Jilid VII, h. 268.

Shihab, Muhammad Quraish. "Wawasan al-Qur'an Tentang Kebebasan Beragama," dalam Komaruddin Hidayat (ed.). Passing Over: Melintas Batas Agama. Jakarta: Gramedia Pustaka Utama, 1999.

Sidahmad, Muhammad 'Ata Alsid. Islamic Kriminal Law: The Hudud. Malaysia: t.p., 1995.

Sudarsono. Kamus Hukum, Cet. 2. Jakarta: Rineka Cipta, 1999.

Suseno, Franz Magnis. Kuasa dan Moral. Jakarta: Gramedia, 1986.

Syahrûr, Muhammad. al-Kitâb wa al-Qur'an: Qirâ'ah Mu'asharah. Kairo: Sinâ li al-Nasyr wa al-Ahallî, 1992.

Zuhaylî, Wahbah. al-Fiqih al-Islâmî wa Adillatuh, Cet. 4, Juz VII. Dimasyq: Dâr al-Fikr alMu'âshir, 2002. 